\title{
Effect of coal moisture on denitration efficiency and boiler economy
}

$$
\text { Y.J.LIAO }{ }^{1} \text {,Q.S.XU }{ }^{1}, \text { S.JI }{ }^{1}, H . Z H A O^{2}
$$

\author{
${ }^{1}$ Electric Power Science Research Institute of Guangdong Power Grid Co., Ltd., Guangzhou \\ 510080, China
}

${ }^{2}$ School of Energy and power Engineering, North China Electric Power University, Baoding 071003,

KEYWORD: Moisture content of coal; Gas inlet temperature at SCR system; Thermal calculation; Denitrification efficiency; Cost

ABSTRACT: Taking a coal-fired unit as the research object, the denitrification efficiency and cost of SCR system are analyzed under burning-coal with different moisture. Though thermal calculation, the gas inlet temperature at SCR system was calculated, then the denitrification efficiency was gotten from the graph of denitrification efficiency and SCR system inlet temperature. Then the costs of the coal and SCR system operation were estimated. The results showed that as the coal with $35 \%$ moisture dropped to $15 \%$ moisture, the gas inlet temperature of SCR system deceased about $10^{\circ} \mathrm{C}$,denitrification efficiency increased to $67.4 \%$ from $54.3 \%$ and the cost of coal and SCR system operation dropped more than 24 million a year.

\section{INTRODUCTION}

Coal quality is an important factor influencing the boiler running economy and environmental protection. In reality, due to factors such as the unstable coal quality, a variety of non-designed coal has been burned to meet the coal combustion and environmental requirements. Based on the above reasons, this article will study on the relationship among the moisture content in the coal and SCR inlet smoke temperature and denitration efficiency and so on.Many scholars have conducted indepth study and achieved fruitful results about the content of this article.Including the influence of coal quality on the exhaust temperature, boiler efficiency, coal consumption ${ }^{[1,2]}$ slagging, the stability of combus-tion ${ }^{[3]}$ and the change on the boiler thermal effi-ciency ${ }^{[4]}$. Coal moisture changes have the effect on the power plants economy ${ }^{[5-7]}$.

On the basis of previous studies and in the view of environmental protection, this paper will focus on the influence of coal moisture on the denitration efficiency and economy. First we should calculate the coal moisture influence on the SCR inlet smoke temperature. Then, building a relationship between coal moisture and denitration efficiency according to the SCR inlet smoke temperature and denitration efficiency curve. Thus it is concluded that the influ-ence of coal moisture on the denitration effici-ency.Using the calculation results to discuss further the situation of the boiler economic operation. It provides the reference for the denitration efficiency improved and costs reduced.

\section{Research object}

Taking a power plant boiler and its checking coal types of Guangdong as a object, its as-received moisture was $35 \%$ and the calorific value is $12800 \mathrm{~kJ} / \mathrm{kg}$. Gradually reducing the moisture on the basis of this standard was 35\%,30\%, 25\%, 20\%, 15\%. The other components changed accordingly. The change of calorific value can be calculated accord-ing to the following formula (1) ${ }^{[8]}$. The influence of coal moisture on received low calo-rific value:

$Q_{a r 0, \text { net }, p}=\left(Q_{a r 1, n e t, p}+25 M_{a r 1}\right) \frac{\left(100-M_{a r 0}\right)}{\left(100-M_{a r 1}\right)}-25 M_{a r 0}$

where $Q_{a r 0, \text { net, } p}$ is the low calorific value of raw coal; $Q_{a r 1, n e t, p}$ is low calorific value of changed coal; $M_{a r 0}$ is the water of raw coal; $M_{a r l}$ is the water of changed coal.The calculation results are listed in Table 1. 
Table.1 The elemental and industrial analysis of coal

\begin{tabular}{l|l|l|l|l|l|l|l|l}
\hline Coalquali-ty & $\begin{array}{l}\text { Moisture } \\
(\%)\end{array}$ & $\begin{array}{l}\text { Carbon( } \\
\%)\end{array}$ & $\begin{array}{l}\text { Hydrogen( } \\
\%)\end{array}$ & $\begin{array}{l}\text { Oxygen } \\
(\%)\end{array}$ & $\begin{array}{l}\text { Nitroge } \\
\mathrm{n}(\%)\end{array}$ & $\begin{array}{l}\text { Sulfur(\% } \\
)\end{array}$ & $\begin{array}{l}\text { Grey( } \\
\%)\end{array}$ & $\begin{array}{l}\text { Low } \\
\text { calorific } \\
\text { valuekJ } \mathrm{kg}^{-1}\end{array}$ \\
Raw coal & 35 & 34.35 & 2.85 & 10.64 & 0.70 & 1.08 & 15.7 & 12800.0 \\
& 30 & 37.00 & 3.07 & 11.46 & 0.75 & 1.17 & 16.5 & 13976.9 \\
Coal mois- & 25 & 39.64 & 3.29 & 12.28 & 0.81 & 1.25 & 17.7 & 15153.8 \\
ture cha-nges & 20 & 42.28 & 3.51 & 13.10 & 0.86 & 1.34 & 18.9 & 16330.7 \\
& 15 & 44.92 & 3.73 & 13.92 & 0.92 & 1.42 & 20.1 & 17507.6 \\
\hline
\end{tabular}

The composition of each element were received as standard

The former electric power ministry to the power plant coal quality parameters range have a clear a regulation that the coal quality parameters based on boiler designed coal, such as in Table 2 .

Table. 2 Coal quality allowed change range

\begin{tabular}{l|l|l|l|l|l}
\hline Coal quality & $\begin{array}{l}V_{\text {daf }} \text { deviation } \\
(\%)\end{array}$ & $\begin{array}{l}A_{\text {ar deviation }}(\%) \\
\text { Lignite }\end{array}$ & $\begin{array}{l}M_{\text {ar }} \text { deviation } \\
(\%)\end{array}$ & $\begin{array}{l}Q_{\text {net,ar }} \\
\text { deviation } \\
(\%)\end{array}$ & $\begin{array}{l}\text { ST deviation } \\
(\%)\end{array}$ \\
\hline
\end{tabular}

Where $\mathrm{V}_{\text {daf, }}$, Aar and Mar are the absolute deviation from designed value; $\mathrm{Q}_{\text {net,ar }}$ and ST are the relative deviation from designed value.

Coal moisture range is from $-5 \%$ to $5 \%$. Due to the reasons such as power plant coal storage conditions and the type of coal and the weather changes, the scope of boiler coal moisture change is difficult to meet the above requirements. Therefore, studying the effect of moisture on SCR inlet smoke temperature has a realistic significance. In addition, the require-ments of water deviation between the largest and smallest is about $10 \%$.However the water deviation calculated is about $20 \%$ considering the actual situa-tion.

\section{Results and discussion}

This paper is calculated to full capacity for the same boiler and coal. The moisture in coal were $35 \%, 30 \%, 25 \%, 20 \%, 15 \%$, respectively. Then the thermodynamic calculation for coal with different water were carried out[10]. Some results are listed in Table 3. 
Table 3 the part thermodynamic calculation results

\begin{tabular}{c|c|c|c|c|c}
\hline Computer projects & $\begin{array}{c}\text { Raw } \\
\text { coal }\end{array}$ & \multicolumn{3}{|c}{ Moisture changes } \\
Moniture in coal/\% & $35 \%$ & $30 \%$ & $25 \%$ & $20 \%$ & $15 \%$ \\
Smoke quantity $/ \mathrm{m}^{3} \mathrm{~kg}$ & 5.24 & 5.87 & 5.94 & 6.02 & 6.17 \\
$\begin{array}{c}\text { Theoretical combution } \\
\text { temperature/ } /{ }^{\circ} \mathrm{C}\end{array}$ & 1814.73 & 1859.52 & 1907.63 & 1940.5 & $\begin{array}{c}1954.5 \\
6\end{array}$ \\
$\begin{array}{c}\text { Exhaust gas } \\
\text { temperature } /{ }^{\circ} \mathrm{C}\end{array}$ & 150.60 & 143.10 & 135.50 & 130.80 & 128.80 \\
$\begin{array}{c}\text { Boiler thermal } \\
\text { efficiency/\% }\end{array}$ & 91.65 & 91.87 & 92.46 & 92.74 & 93.14 \\
$\begin{array}{c}\text { Fumace exit gas } \\
\text { temperature } /{ }^{\circ} \mathrm{C} \\
\text { Actual fuel }\end{array}$ & 996.25 & 997.72 & 994.52 & 987.96 & 985.48 \\
$\begin{array}{c}\text { consumption } / \mathrm{kg} \cdot \mathrm{h}^{-1} \\
\text { SCR inlet smoke } \\
\text { temperature }\end{array}$ & $\begin{array}{c}222233 . \\
6\end{array}$ & $\begin{array}{c}219483 . \\
0\end{array}$ & 215461.4 & 212864.8 & 210956 \\
& 414.95 & 413.94 & 410.87 & 405.93 \\
\hline
\end{tabular}

The coal calculated is derived from raw coal which changed water content. In order to analyze the subsequent boiler economy, different moisture of coal consumption(B') have converted into corresp-onding raw coal consumption(B) according to the type (2) in the Table 3.

$$
B=B^{\prime} \cdot \frac{100-M_{a r}^{\prime}}{100-M_{a r}}
$$

where Mar is the raw coal moisture, Mar is the moisture of coal quality after changed. We can see from Table 3 that coal consumption is arising trend with the increase of coal moisture.This is because the reduced moisture increase calorific value. When the water rose from $15 \%$ to $35 \%$, coal consumption rose from $210956.4 \mathrm{~kg} \cdot \mathrm{h}^{-1}$ to $222233.6 \mathrm{~kg} \mathrm{~h}$. Unit fuel can produce smoke gas quantity from $6.17 \mathrm{~m}^{3} \cdot \mathrm{kg}^{-1}$ down to $5.24 \mathrm{~m}^{3} \cdot \mathrm{kg}^{-1}$ and reduce the rate of $9.53 \%$.

\section{The influences of coal water on the smoke temperature}

The relations between coal with different water and SCR inlet smoke temperature, combustion and exhaust temperature are shown in Fig 1. As you can see, SCR inlet smoke temperature with the same as outlet smoke temperature from heating surface with declining coal moisture. This is a real downward trend. When moisture content decreased from $35 \%$ to $15 \%$, SCR inlet smoke temperature dropped nearly $10^{\circ} \mathrm{C}$. Theoretical combustion temperature rose from $1814{ }^{\circ} \mathrm{C}$ to $1954{ }^{\circ} \mathrm{C}$ and rose by about $140{ }^{\circ} \mathrm{C}$.Exhaust temperature reduced from $150^{\circ} \mathrm{C}$ to $128^{\circ} \mathrm{C}$ and fell by about $22^{\circ} \mathrm{C}$. 


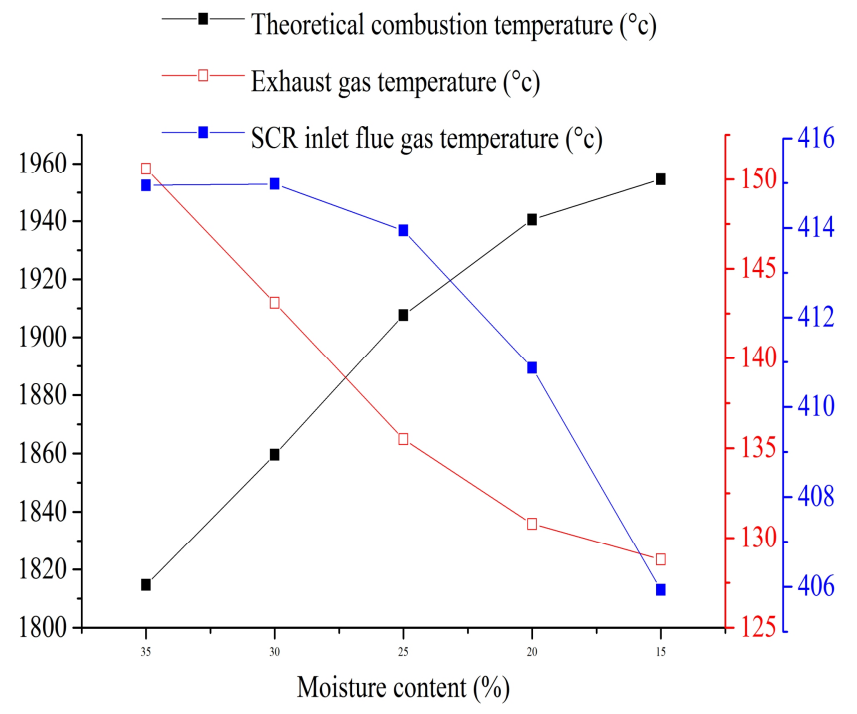

Fig. 1 SCR inlet temperature, exhaust temperature and smoke theoretical combustion temperature

This trend may be due to the reason that coal moisture increased from $15 \%$ to $35 \%$ making calorific value of coal fell.The theoretical com-bustion temperature will be greatly reduced. At the same time, it also will lead to a rise in coal consumption. Therefore, the smoke quantity will rise sharply. Increased smoke volume and lower com-bustion temperature will reduce the effect of heat convection at the heating surface. The flue gas temperature dropped amplitude decreases and the logarithmic temperature difference of heating sur-face reduces. So the temperature dropped along the gas flow direction become smaller.The SCR inlet smoke temperature and exhaust gas temperature are increased.

\section{The influences of coal moisture on the denitration efficiency}

The relations between SCR inlet smoke tem-perature and denitration efficiency are shown in Fig.2. The figure shows that when SCR inlet smoke temperature changes in the range of $380^{\circ} \mathrm{Cto}$ $396{ }^{\circ} \mathrm{C}$, the denitration efficiency increased with the rise of the flue gas temperature. Denitration efficiency reached the maximum when the flue gas temperature is $396^{\circ} \mathrm{Cor}$ so. So the plant denitration system optimum reaction temperature is $396{ }^{\circ} \mathrm{C}$. When the smoke temperature continues to rise, denitration efficiency began to decline. When the smoke temperature rise to about $410^{\circ} \mathrm{C}$, denitration efficiency would be reduced to $59.8 \%$.

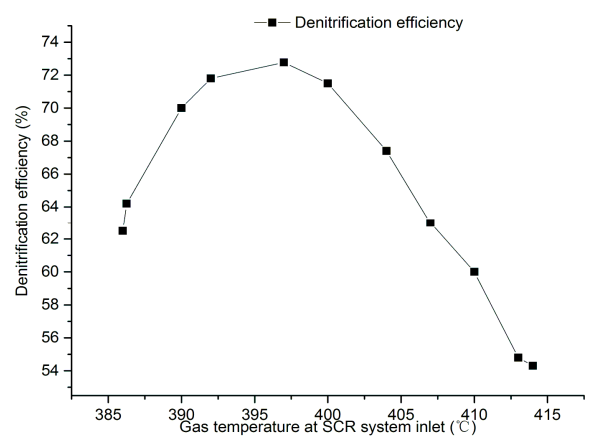

Fig. 2 Influence of flue gas temperature on the denitration efficiency

According to the Fig.2 and the calculated SCR inlet smoke temperature, we get the relations among coal moisture, SCR inlet smoke temperature and denitration efficiency. It is listed in Table 4. 
Table. 4 Relations among coal moisture, SCR inlet smoke temperature and denitration efficiency.

\begin{tabular}{llllll} 
Computing projects & $\begin{array}{c}\text { Raw } \\
\text { coal }\end{array}$ & \multicolumn{4}{c}{ Moisture changes } \\
\hline $\begin{array}{l}\text { Moisture in coal/\% } \\
\text { SCR inlet smoke }\end{array}$ & $35 \%$ & $30 \%$ & $25 \%$ & $20 \%$ & $15 \%$ \\
temperature $/{ }^{\circ} \mathrm{C}$ & 414.9 & 414.9 & 413.9 & 410.8 & 405.9 \\
$\begin{array}{l}\text { Denitration } \\
\text { efficiency/\% }\end{array}$ & 54.3 & 54.3 & 54.8 & 60 & 67.4 \\
\hline
\end{tabular}

Table. 4 shows that when raw coal moisture up to $35 \%$, denitration efficiency is about $54 \%$. Denitration efficiency increases when the raw coal moisture falling.Coal moisture decreased from 35\% to $15 \%$, the denitration efficiency increased from $54.3 \%$ to $67.4 \%$. The reasons for the trend is likely to be SCR inlet smoke temperature (denitration temperature) of the research units is higher than that of catalyst optimum reaction temperature. When the denitration temperature is greater than the optimum reaction temperature, the $\mathrm{NH}_{3}$ will react with $\mathrm{O}_{2}$ and $\mathrm{NO}_{\mathrm{X}}$ generated. Den-itration efficiency become lower because of higher concentration of $\mathrm{NO}_{\mathrm{X}}\left[{ }^{11-13]}\right.$. It appears a phenom-enon that denitration efficiency decreases with the increase of denitration tem-perature .

\section{The influences of coal moisture on the denitration cost}

Fuel consumption decreased by $11277.2 \mathrm{~kg} / \mathrm{h}$ when coal moisture decreased from $35 \%$ to $15 \%$.According to the provided data from power plant, a ton coal prices by 360 yuan and the boiler running $6000 \mathrm{~h}$ a year, which can get coal cost down 24.3588 million yuan a year. Coal moisture content is reduced causing nitrogen element content is relatively higher, but the total coal consumption is decreased. For convenient, SCR inlet $\mathrm{NO}_{\mathrm{X}}$ concentration is calculated according to the designed standard of $550 \mathrm{mg} / \mathrm{m}^{3}$. $\mathrm{NO}_{\mathrm{X}}$ emissions can be calculated from the smoke gas quantity and denitration efficiency. The environmental protection department for $\mathrm{NO}_{\mathrm{X}}$ emissions proves fee methods[14]. With $200 \mathrm{mg} / \mathrm{m}^{3}$ for the prescribed discharge standards can calculate the corresponding $\mathrm{NO}_{\mathrm{X}}$ fines. Further increases in denitration effi-ciency will increase ammonia consumption and the cost of denitration. Ammonia consumption costs will be achieved under the condition of ammonia nitrogen ratio 1:1. 2 and ammonia price 3000 yuan a ton. This article will ignore other costs such as the artificial and denitration operation electricity. It is adopted that small proportion in the cost of coal and denitration .All the results are listed in Table 5.

Table 5The summary of estimated cost (ten thousand yuan a year)

\begin{tabular}{|c|c|c|c|c|}
\hline $\begin{array}{l}\text { Moistue } \\
\text { in coal } \\
(\%)\end{array}$ & $\begin{array}{l}\text { Coal-fired } \\
\text { cost }\end{array}$ & $\begin{array}{l}\text { Polluta- } \\
\text { nts fines }\end{array}$ & $\begin{array}{l}\text { Ammonia } \\
\text { consumption } \\
\text { cost }\end{array}$ & $\begin{array}{l}\text { Combined } \\
\text { cost }\end{array}$ \\
\hline 35 & 48002.46 & 2985.52 & 425.68 & 51413.66 \\
\hline 30 & 47408.44 & 3303.08 & 470.96 & 51182.48 \\
\hline 25 & 46539.66 & 3245.32 & 472.15 & 50257.13 \\
\hline 20 & 45978.80 & 2875.56 & 517.60 & 49371.96 \\
\hline 15 & 45566.58 & 2380.44 & 590.58 & 48537.60 \\
\hline
\end{tabular}

Table 5 shows that coal cost can save 24.3588 million yuan/year when the coal moisture content decreased from $35 \%$ to $15 \%$.At the same time due to the denitration efficiency increased and pollutant emissions reduced,and the charges for pollutant emissions reduces about 6 million yuan a 
year.With the corresponding cost of ammonia caused by the increase of ammonia consumption increased about 1.65 million yuan a year.Through comprehensive analysis, with the Coal moisture reduction, it is that the cost of coal will be reduced. With denitration efficiency increased, the cost of denitration operation would be blow down. At the same time the catalyst is not easy to jam because coal moisture reduced.The service life of the catalyst improved can save catalyst replacement cost indirectly.So the reduced coal moisture will eventually bring the high economic benefits for power plant.

\section{Summary and conclusions}

This paper conducted thermodynamic calculation aiming at a coal-fired units checking coal with water content of the different types.It analyzed the influence of coal moisture on the flue gas temperature at heating surface, especially the influence on SCR inlet smoke temperature.The calculation results show that:

1)With coal moisture content decreased from $35 \%$ to $15 \%$, the overall declining SCR inlet smoke temperature showed a declining trend and the falling range is about $10{ }^{\circ} \mathrm{C}$.

2)With coal moisture content decreased from $35 \%$ to $15 \%$, the denitration efficiency increased from $54.3 \%$ to $67.4 \%$ and ascensional range is about $13 \%$.

3)With coal moisture content decreased from $35 \%$ to $15 \%$, the coal consumption of unit reduced. The coal cost has fallen dramatically and saved 24.3588 million yuan a year.

4)Denitrationefficiency increased when the coal water reduced. Pollutant discharge fees dropped by about 6 million yuan a year.But the cost of ammonia consumption increased about 1.65 million yuan a year.

5)In a word, when the coal moisture content decreased from $35 \%$ to $15 \%$, total coal and denitration operation cost down 28.76 million yuan a year and greatly reduces the power plant operation cost.At the same time pollutant emission reduction can reduce the environmental pollution.So, reducing the coal quality water not only has economic benefits but also the environmental benefits for power plant.

\section{References}

[1] Y.Y. ZHAO, G.B. ZHAO \& H. LIU. The impact of the lignite water on thermal performance [J].Energy conservation technology, 2013, 31(180):317-320.

[2] Z.M. JIN \& Y.C. SONG. Comparison of economic influence of moisture and ash content in steamcoal on boiler operation[J]. Zhejiang electric power, 2012, (6):31-33+76

[3] W. YAO, L.F. HAN, N. XUE, G.F. WANG,Y. MENG \&J.L. LIU. The influence of coal for power plant boiler operation [J]. Thermal power generation,2005,(07):22-26+1

[4] Z.G. SUN.The influence of coal moisture and calorific value on exhaust gas temperature and the boiler efficiency[J].Boiler manufacturing,2010,(02):19-22

[5] Q.D. LI, M. LIU \&J.J. YAN. Thermal economic calculation and analysis for boiler flue gas predried lignite-fired Power Generation system [J]. Proceedings of the CSEE, 2012, (20): 14$19+133$.

[6] W. Wu,W.P. YAN \&H.F.REN. Study on the economy influence of drying lignite with steam in the power plant [J]. Electric Power Science and Engineering, 2012, (09):57-62.

[7] W.P. YAN, K. MA \& C.Q. LI. Economical effect of lignite coal drying on coal-fired electric power plant [J] Electric Power, 2010, (03): 35-37

[8] Z.H. HAO. The development of baffle downer dryer for lignite dewater with high temperature flue gas and the research of key technologies[D].Tsinghua University, 2011.

[9] Certain rules to strengthen the management of large coal-fired boiler combustion[S].

[10]Z.Y. GAO, J.D. LI, Y.Z. FAN, S.T. CHEN \& P.X. WU. Influence of lignite dryness on heat transfer and operation economy of power boilers[J]. Journal of Chinese society of power engineering, 2014,(03):182-188+227.

[11]J.P. LI, J.F. LV, Q. LIU \&G.X. YUE. Low NOx emissions technologies of pulverized coal jet 
combustion process[J]. Boiler technology, 2005,(06):25-31.

[12] Guido Busca, Luca Lietti, Gianguido Ramis\& Francesco Berti. Chemical and mechanistic aspects of the selective catalytic reduction of NOx by ammonia over oxide catalysts: A review[J]. Applied Catalysis B, Environmental,1998,(18):1-36.

[13]X.J. ZHAO \&J. SUN. Factors influencing the denitration efficiency of SCR in Jinzhou cogeneration power company limited[J]. North China electric power technology,2011,(06):1821.

[14] «The collection standard of Tianjin pollutantcharges for disposing pollutants adjust to implement ladder type differential charges» 